\title{
The Contribution of English Gossip Magazine on Students' Enthusiasm in Speaking Ability
}

\author{
Ismail Ismail \\ Email: smileummaspul@gmail.com
}

\section{STKIP Muhammadiyah Enrekang, Indonesia}

\begin{tabular}{|c|c|}
\hline Keyword & Abstract \\
\hline $\begin{array}{l}\text { English Gossip } \\
\text { Magazine, } \\
\text { enthusiasm, } \\
\text { authentic materials, } \\
\text { webzines, speaking } \\
\text { ability. }\end{array}$ & $\begin{array}{l}\text { This current study sought to reveal the impacts of corpus-based activities on } \\
\text { verb-noun collocation learning in EFL classes. This study was carried out on } \\
\text { two groups - experimental and control groups- each of which consists of } 15 \\
\text { students. The students were preparatory class students at School of English } \\
\text { Department, STKIP Muhammadiyah Enrekang. Before the treatment, a pretest } \\
\text { was administered to both groups. The results of the pretest demonstrated that } \\
\text { there was not significant difference between the control and the experimental } \\
\text { group. Throughout the study, the experimental group was taught speaking } \\
\text { through English Gossip Magazine materials taken from webzines, and the } \\
\text { control group was taught through a conventional method. The results } \\
\text { demonstrated that there is a statistically significant difference between } \\
\text { experimental and control group in terms of the type of treatment, which signifies } \\
\text { that English Gossip Magazine as a resource of learning material activities has a } \\
\text { significant contribute on speaking development in EFL classes. }\end{array}$ \\
\hline
\end{tabular}

\section{INTRODUCTION}

Communication is a process which occurs delivering a message by one person to another in the form of verbal and non-verbal or verbally (directly) or indirectly (through the media). Social interconnections are complex, and it is impossible to be present at many primary exchanges to absorb this kind of information directly. Thus, many people are eager to pick it up through an intermediary, whether or not they have the luxury and patience to confirm it later either directly or indirectly. This phenomenon, of course, is called gossip. It is an important social behavior that nearly everyone experience, contributes to, and presumably intuitively understand, (Foster, 2004).

Gossip is a phenomenon that occurs in everyday life (Katerina, 2014). Dunbar (2004) reports results from a series of studies on the content of everyday conversations, showing that gossip accounts for approximately $65 \%$ of speaking time. Two-thirds of all human conversation is gossip, because this vocal grooming is essential to our social (Fox, 2001). Gossip is a way of communicating rules and establishing norms; it is informal and leads to sharing of information and risk (Noon\&Delbridge, 1993). This informality of communication is an important characteristic of gossip and plays an important role, especially when gossip occurs in the workplace, where the formal path might be ignored, (Roberts \& O'Reilly, 1978).

Gossip as verbal evaluates communication among no more than a few individuals, about another who is or is not present (Michelson, van Iterson, and Waddington, 2010). The word ' gossip' means a conversation or reports about other people's private lives which might be unkind, disapproving or not true, (Cambridge Dictionary). Foster (2004) assert that people need to acknowledge other people through the 
amount of information that they get about them in order to be able to live effectively in this kind of social situation that is considered complicated. Gossip, then, becomes one of the tools that people use in reinforcing the bond in social relation.

Whatever its moral status, there is certainly some evidence to suggest that gossip is a deep-seated human instinct: evolutionary psychologists have compared the evolution of gossip in humans with the practice of 'social grooming' among chimps where the animals spend hours grooming each other's fur, even when they are perfectly clean, as a form of social bonding. This would indicate that gossip, far from being a trivial pastime, actually performs a vital and socially therapeutic function (Fox, 2001).

Nycyk (2015) state that the effect of gossip and rumour can make somebody's identifies and reputation labelled negatively. Gossip can be seen as an unimportant activity which has no benefit. However, opposing the previous statement that highlight the negative value of gossip, Baumeister, Zhang, and Vohs (2004) note that gossip is not only about negative instances of rule breaking, but it can be about positive instances of rule strengthening. Dunbar (2004) also argues that "gossiping (perhaps not gossip in its malicious form) is the core of human social relationships, indeed of society itself. Without gossip, there would be no society". An interesting finding from Ellwardt, Labianca, and Wittek (2012) reveals that both positive and negative gossip is more likely to be spread about colleagues within the same work group and not the out-group.

Traditionally gossip is seen as a negative issue, which in the context of the organization needs to be minimized if not eliminated at all. One of the most observable negative aspects of gossip is the damage it can do to relationships and to the reputations of other persons and their stature in the workplace (Kurland \& Pelled, 2000). Some organizations link gossip to negative outcomes such as decreased productivity, eroded morale, hurt feelings and reputations, and the turnover of valued employees (e.g., Danziger, 1988). Michelson and Mouly (2000) similarly conclude that much of the popular business literature tends to treat rumour and gossip as a detrimental activity for organizations as gossip was assumed "to waste time, undermine productivity".
People might not realize that they engage gossip in every conversation that they have. Gossip considered as an unofficial way of daily communication that relates to the process of placing, interpreting, and rebuilding the information that oppose the situation of one's particular social status and advantage (Meyers, 2010). Some people commonly understand gossip as meaning the spreading of rumour and misinformation, as (for example) through excited discussion of scandals. Some newspapers carry "gossip columns" which retail the social and personal lives of celebrities or of elite members of certain communities. The word gossip the usually relates to the phenomenon of celebrity and fame: "celebrities are ideal object of gossip talk because their widely circulated images are easily accessible ideological symbols" (Schickel, 1986; Dyer, 1998; Turner, 2004 as cited in Meyers, 2010, p. 6). In addition to the relation between gossip and celebrity, Turner (2004) as cited in Meyers (2010) points out that that idea of celebrity is different compared to other public figures because when people become celebrities means that they should be ready to allow other people, even strangers, to come into their private lives which means in this case that the private lives of celebrities become more interesting than the achievement that they already get because it will maintain the celebrities ${ }^{\text {ee }}$ popularity. The phenomenon of gossip that appears in some popular literary works such as Gossip Girl, and Everyone Worth Knowing also indicate the relation between famous people and gossip.

Gossiping is generally drifted of negative chat among women. However, it sounds too gendered bias since men also do lots of gossiping. In general, people have a tendency to spend hours gossiping other people's life. Even, in some newspaper or magazines, some TV programs, we can find stories about the social and private lives of famous people. As gossips may contain true and lifelike story, some people prefer to tell a secret of others' personal life to someone who they trust not to tell anyone else. Though this activity connotes negative meaning, it will be too immature to bear in mind that gossips are of no value.

Pedagogical issues concerning the
contribution of Gossip English magazine in
educational context


The place and role of Gossip English magazine in school is quite controversial and opinions regarding its use in educational settings are divided, many voices claiming that it interferes negatively with the school and leads to unwanted behavior from students. Certainly are also disadvantages, however, the pedagogical advantages are obvious.

According to some authors who have studied the field (Averianova, 2012), two important reasons lead to banning Gossip English Magazine in school: educational reasons and linguistic reasons.

From the pedagogical point of view there is more than a single perspective regarding the contribution of the Gossip English Magazine in the educational context. On the one hand, there is a well-known orientation that tries to adapt instructional approach to learning styles and educational needs of students. In this regard, Gossip English Magazine offers new ways of creating and disseminating knowledge, which can solve some of these requirements. Of no less importance, among many positive aspects, is the ecological tests: the online "paperless" test is an example. On the other hand, another point of view claims the inappropriate use of the devices in schools. Phone calls during class are disruptive to the classroom atmosphere, as suggested by an experiment conducted in this regard. Thus, disruption of teaching lecture several times because of the ringing of a mobile phone affects quite seriously the learning atmosphere in the classroom and leads to a significant decrease in academic performance of students (End et al., 2010).

Text messaging during class tasks involves focusing attention away from educational issues, or at best, leads to the multitasking element that affects primary task performance. Educational practice is also full of reports of fraud by using mobile phones; also, numerous cases of harassment (cyberbullying) are reported, bullying, gossip and other antisocial activities conducted by phone. From the linguistic point of view, the problems are related to how pupils write the text messages (alternate language development) and to difficulties in acquiring handwriting skills (Averianova, 2012).

We gossip a lot. Most of the muchvaunted human capacity for complex language is dedicated to gossip. Perhaps the most striking finding of recent research on human conversations is that about two thirds of our conversation time is entirely devoted to social topics: discussions of personal relationships and experiences; who is doing what with whom; who is 'in' and who is 'out' and why; how to deal with difficult social situations; the behaviour and relationships of friends, family and celebrities; our own problems with lovers, family, friends, colleagues and neighbours; the minutiae of everyday social life in a word, gossip (Fox, 2001).

As gossiping involves at least two interlocutors, there must be a good point of gossiping to take to the language learning activities. The value of gossiping may lay on real talk as they are free forms of conversation. Gossiping deals with rich pragmatic discussions indicated by lots of paratactic and paralinguistic features as it is spoken. The occurrence of spoken language features adds rows to the plus point of gossip materials. Rather than rumbling around of gossiping people purposeless, it will be useful to take gossips as one way to improve speaking fluency in EFL learning.

We may also gossip because we are genetically programmed to do so. According to the psychologist Robin Dunbar (1996) (to whom we owe most of the above findings on gossip), gossip is part of our evolutionary hard-wiringperhaps even the single most important part. Language, he argues, evolved to allow us to gossip. Language evolved to fill the 'grooming gap', because it allows us to use the limited time we have available for social interaction keeping in touch and bonding with a wide social network more efficiently (Fox, 2001).

Nevertheless, fluency in using spoken English can only be attained when students always chat in English. In many cases, it is typical to find students who looked more enthusiastic to speak in unstructured conversations. Sometimes they whisper and more often they yell and jump when they find the topic of their interest is on the talk. From such cases, it is worthy of assuming that gossips may be used as language learning materials; that although gossips contain negative connotation, the effects or perhaps the impacts on students' language learning may turn to be positive. This will be true if the materials are appealing, are well-planned or well-organized and they are more about people who are not anticipated to perform negative behaviours. 
It is clear that many students in the context of EFL feel challenged to use spoken English in real situations and many EFL teachers find it difficult to teach oral English because they do not come into contact with native English speakers. Malaysian ESL learners are also reported to have similar difficulties in English oral communication activities (Norafini, 93-112). Gossip can serve as a source of spoken English and may increase the enthusiasm in speaking. Some educators argue that this is low culture and not enough arrange for students to make progress. However, if we want to develop independence in speaking and understanding, we need to engage students and increase their interest, and most importantly, their self-esteem. What many magazines are offered in various forms is an element of gossip. Gossip comes in many guises, it can be about movie stars, music artists, football, celebrities, historical figures - and has been proven many times, people love gossip. It should not have a negative connotation; it can be driven as information sharing, as well as the opportunity to discuss current affairs and socially relevant topics. When it is based on the revelations of a famous person, and not the personal behavior of students it gives us all the opportunity to discuss the issues in a way that is less personal.

Enthusiasm is not merely a figure of speech; it is a vital force that people can exploit and use with profit. In speaking, enthusiasm is a necessity that should be bound to develop dynamic personality. The question to ask in this point is that what actually enthusiasm is and how it is connected with speaking. Enthusiasm is defined in Cambridge Advanced Learner Dictionary (2008:CD-ROM Version) as "a feeling of energetic interest in a particular subject or activity and an eagerness to be involved in it." As a feeling, enthusiasm involves sensory to enable an organism understands, recognizes, values or reacts to something physically. Energetic interest is a reaction or response of a powered stimulus in a particular activity that results in excitement or pleasure.

Brainy Quote (2008), enthusiasm is defined as "an inspiration as if by a divine or superhuman power; ecstasy; hence, a conceit of divine possession and revelation, or of being directly subject to some divine impulse." This definition emphasizes on the power of joy that gives people an idea for doing something.

In today's globalize world, examples abound, but the most commonly used perhaps are: newspapers, TV programs, menus, magazines, the internet, movies, songs, brochures, comics, literature (novels, poems and short stories), and so forth. Here, the researcher would like to look at magazines (printed or online) as authentic materials in a bit more detail and then move on to a variety of sample tasks.

Magazine in Cambridge Advanced Learner Dictionary (2008:CD-ROM Version) is defined as "a type of thin book with large pages and a paper cover which contains articles and photographs and is published every week or month." For a magazine that is published on the Internet and not on paper is called a webzine. Magazine or webzine is an excellent source for a study text or written manuscript. Most magazines use good syntax, relatively simple sentences, and common expressions. In addition to general vocabulary, magazines provide many common political, scientific, economic, entertaining or leisured and technical words. Generally, magazines are also a good source of colloquial expressions.

According to Lundquist (2008:24), magazines or newspapers provide language teachers and language learners a great choice of: spoken vocabulary; meanings for real target language; syntax development; learning new expressions or gambits; fluency enhancement; and real conversation practice.

EGM is a magazine contains articles or news mostly about fames and celebrities in film and music industries, sports, political pouch and the like. The purpose of using the EGM in this study is for spoken language practice and for enthusiasm encouragement. For this reason, a printed magazine or webzine text would assure a more precise use of the language, better spelling, and a more easily preserved printed copy. As many students' especially young adolescent or pre-adult learners prefer to read magazines and comics, and like to talk about celebrities of their idols, EGM can be the best choice of enhancing students' enthusiasm in speaking spoken English.

With the advent of the www, teachers have at their disposal large amounts of texts, visual stimuli, newspapers and magazines, live radio and $\mathrm{TV}$, video clips and much more. There 
are endless lists of useful materials for the language classroom. For online magazines or webzine, there is no point in asking students to just go to the web and read some text or other. There needs to be a task, preferably one in which meaning is central and has some connection to the real world. Treasure hunts and other information searching activities are probably the most useful. Asking students to look for actual gossips around personal life of famous celebrities from www like David Beckham and his family, Britney Spears, Tom Cruise, etc., will be a great experience of students as they are involved in materials development. Besides, the resources are not difficult to search as most of the students are quite familiar with internet and celebrities. Such resources should then be adopted through a careful evaluation and adapted according to predetermined language learning needs in the syllabus. For this reason, EGM will not harm Indonesian's norms and value system as the gossips are valuable for learning purposes.

To be prompt, Kitao and Kitao (2003) suggest that there are many possible sources of materials. There is a lot of material available on the Internet such as webzines or online news that they can search for in their free time, and store them for future classes. Besides, many teachers go abroad during vacations these days, and they can collect materials in Englishspeaking countries. TV and radio are good sources too. They provide a variety of materials. The information is current and the language is natural, but the content has to be chosen carefully. Newspapers, English gossip magazines (EGM), advertisements, and other types of printed material or online material are very useful. Teachers can take photos; make video tapes or record audio tapes. If they make plans before they go overseas, they may be able to make good video or audio programs. Even in their home country, they can browse the World Wide Web (www) and search for useful materials for classes.

Recognizing the contribution of English gossip magazine on speaking development, we decided to implement them in a fundamental course to solve traditional learning problems and to make the learning process more efficient. Our main focus was put only on speaking skill. It is hoped that the third year students taking this course would take part in a new learning environment that make enthusiasm them to learn without limit of time and place. The findings of this study may potentially provide insights into unlocking how students learn a foreign language. The information derived from the study will be useful for the administrators in adjusting the teaching and learning process to attract the students' enthusiasm. This study was posed by the following three research questions:

1. Is there a significant difference the students' enthusiasm in speaking ability after the intervention of the topic English gossip magazine?

2. What were the students' respond about the contribution EGM as a learning resource in speaking English?

3. How much did the students speak spoken English if they were exposed to gossip materials from EGM?

\section{METHODOLOGY}

\section{The Participants}

This study employed a quasiexperimental and placed in the quantitative paradigm as a collection of information is quantitative and objective statistical analysis. This study design is 'comparative-time-series' use of the control group. The use of a control group is aimed to minimize the effect of variable timing control. In learning a foreign language, the length of time spent in learning can be used as control variables that can affect the dependent variable. For this reason, each group was given a different treatment four times followed by the same set of observations for each treatment.

The participants were students of three semesters of English Education Department STKIP Enrekang Muhammadiyah. They are at the age of 19. The study participants were 30 students who were selected through random sampling and assigned into experimental and control groups. From the selected sample, 15 students randomly assigned to the experimental group and 15 students in the control group. Each group consisted of random or mixed levels of ability speaking ability. For this reason, they have been selected through a speaking test before the observation begins. Most students interested in learning the language through English Gossip Magazine (EGM), and they complained about the time given to practice English during regular English classes. For this 
reason, participants are selected, all students willingly agreed to participate in this study.

\section{Instrument and Procedure}

This study uses three types of instruments to collect data from a sample. All the instruments have undertaken a series of tests the validity of using the correlation coefficient and have met the standard criteria for concurrent validity. They are accepted as a measure used in this study and was approved at the level of concurrent validity.

\section{Speaking Test}

Speaking test is used to collect information about students' abilities before in English. The results are used to group students in the experimental group and the control to get the mix-ability groups. It is important to avoid bias in terms of intervening variables previously capabilities. All items have undergone item analysis and testing to establish reliability in the group are not selected to participate in this study. Kuder-Richardson coefficient of internal consistency of the instrument was 0.85 (very strong). Therefore, it is unacceptable that the most chosen item has good reliability and power of discrimination. Data obtained from the instrument analyzed and interpreted using the Statistical Package for Social Sciences (SPSS). The researchers used the average value of a set of observations, standard deviation and percentage. For this reason, the researchers set the level of the average have a description of the quality of their enthusiasm in learning spoken English, as follows: (1) 00 to $1.80=$ enthusiastic, (2) 81-2.60 = basically enthusiastic, (3 ) 61 to $3.40=$ less enthusiastic, (4) $41-4.20=$ quite enthusiastic, (5) $21-5.00=$ very enthusiastic.

\section{Observation Check-List (Format of Enthusiasm Observation Assessment) Observation check-list for Enthusiasm} was used to collect the data about the students' enthusiasm in speaking. It was in the form of 5Point Attitudinal Likert Scale of measurement (1 to 5). The item wording was in the form of positive and negative statement with five options from 'always' to 'never'. All of the items had already endured an item analysis and pilot test to inaugurate reliability in a group not selected to participate in the study. The Kuder-
Richardson coefficient of internal consistency for the instrument was .59 (fairly strong). Therefore, it is acceptable that most selected items had good reliability and discrimination power.

Observation check-list for the enthusiasm used to collect data about the enthusiasm of the students in the language. It was in the form of 5point Likert Scale Attitudinal measurements (1 to 5). Item words in the form of positive and negative statements with five choices of 'always' to 'never'. All items are already experiencing item analysis and reliability testing to formalize the group elected not to participate in this study. Kuder-Richardson coefficient of internal consistency of the instrument was 0.59 (strong enough). Therefore, it is unacceptable that the most chosen item has good reliability and power of discrimination.

\section{Observation Check-List (Format of Spoken English Production)}

Observation check-list for spoken English production was used to collect the data about the number of spoken English expressions the students produced during the observation through the turn-taking that was taken over. The format of observation was in the form of frequency tabulation which was added up in every observation. The researcher used the descriptive statistics (frequency and mean level) of students' utterances of spoken English from the observation form. For this reason, the researcher set the norm reference to determine the frequency level to have the description of the utterance quantity. Based on the observation, the highest average amount of spoken English produced was 7.25 and the lowest was 2.50 . The range was 4.75 .

\section{RESULT}

In this study, several things have been deduced. First, the subjects seem to have relatively low level of enthusiasm in learning spoken English before exposing to gossip materials taken from webzines. In the threeseries of treatment and observation, the subjects show a significant tendency to improve their level of enthusiasm from time to time. Second, the subjects in the experimental group show their enthusiasm level to be very much different from those in the control group. They outweigh their peers in the control group in terms of 
enthusiasm level. Third, the subjects of the study also seem to have relatively positive opinions on the use of gossip materials taken from magazines as their level of enthusiasm increases to a greater extent. Fourth, the average mean score of the students' spoken English production in all series measured by the number of turn-taking they can take over is interpreted as having less opportunity (Less Frequent) to produce spoken English. To have more understanding about the findings above, the writer discusses them using the key issues investigated in this research.

The observation results on students' enthusiasm in learning spoken English of the experimental group was taken from four series of observation. The students were given different readings from webzines (The Ultimate Hollywood Gossip Magazine: http://showtalker.net) using gossip topics of the scandals between Britney Spears, David Beckham, Victoria Beckham and Paris Hilton (See Appendix 5). The gossips about these Hollywood celebrities of film and sports had been modified for the purpose of this research to give greater impacts to students' curiosity and enthusiasm. For the purpose of the time-series model, the researcher used the post-observation of every series which consisted of four series. For the control group, the researcher used materials from Scholastic Magazines with different serious topics (Free Talk; No Smoking; Out of This World; Is Global Warming Serious Problem?). In every series of learning, there was a post-test to measure the students' time-to-time enthusiasm in using spoken English.

Therefore, this section is divided into three parts, namely (1) Description and Improvement of the Students' Enthusiasm in Learning Spoken English; (2) Difference of the Mean Score of Both Groups; (3) Students' Opinions about EGM as A Learning Resource in Learning Spoken English; and (4) Amount of Spoken English Exposed.

\section{The Description and the Improvement of the Students' Enthusiasm in Learning Spoken English}

Figure 2 shows the graphic lines of the mean score for enthusiasm in learning speaking English for the experimental and control group.

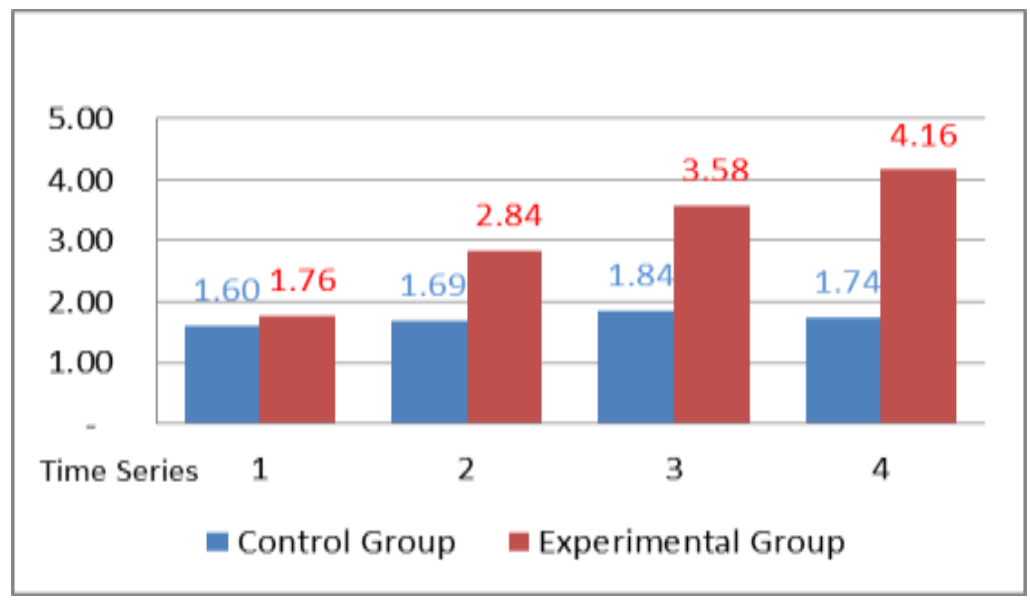

Figure 1 Graphic Line of the Students' Enthusiasm

The data in Figure 3 illustrate that in the first observation for the control group, the mean score is 1.60 and increases to 1.69 in the second observation. In the third observation, the mean score increases slightly to 1.84 and decrease to 1.66 in the last observation. Such mean scores are classified as 'Unenthusiastic' in the predetermined mean level of standard criteria of enthusiasm in learning spoken English.
For the experimental group, the mean scores of enthusiasm in learning spoken English tend to increase gradually to a greater extent. The mean score in the first observation after the first series of treatment is 1.76 which is to some extent similar to those in the control group. After the second treatment, the mean score increases to 2.28 and continue to increase in the third observation to 3.58 . In the last observation, the mean score records a significant increase to 
4.16. Compared to the predetermined mean level of standard criteria of enthusiasm in learning spoken English, the students' enthusiasm increases from 'Unenthusiastic' to 'Highly Enthusiastic' in the last observation.

Thus, in general, the graphic lines in the middle of the chart of the two groups after four series of observation show a different tendency. The graphic line for the control group tends to level off while the graphic line for the experimental group tends to increase. The average increase of the mean scores of the control group is about 3.28 percent while of the experimental group is about 49.62 percent.
Furthermore, table 3 shows the summary statistics of both sample groups. The mean score of enthusiasm in learning spoken English for the experimental group is 4.1213 and 1.6633 for the control group. The standard deviations of both sample groups are between 3.00 and +3.00 . It means that the mean scores for individuals in the groups are in normal distribution. The mean scores of both groups are obviously different but to be able to determine of whether the difference is significant or not, the researcher used the t-test score for independent sample t-test in table 1 .

Table 1 Group Statistics of Enthusiasm in Learning Spoken English

\begin{tabular}{|cl|r|r|r|c|}
\hline & & & & & Std. Error \\
& Group & $\mathrm{N}$ & Mean & Std. Deviation & \multicolumn{1}{c|}{ Mean } \\
\hline Mean_Scores & Exp & 15 & 4.1213 & .04998 & .01291 \\
& Cont & 15 & 1.6633 & .07862 & .02030 \\
\hline
\end{tabular}

Table 2 Independent t-test Score for Enthusiasm in Learning Spoken English

\begin{tabular}{|c|c|c|c|c|}
\hline & & & \multicolumn{2}{|c|}{ Mean Scores } \\
\hline & & & $\begin{array}{c}\text { Equal variances } \\
\text { assumed }\end{array}$ & $\begin{array}{c}\text { Equal variances } \\
\text { not assumed }\end{array}$ \\
\hline \multirow{11}{*}{$\begin{array}{l}\text { Levene's Test for } \\
\text { Equality of } \\
\text { Variances } \\
\text { t-test for Equality } \\
\text { of Means }\end{array}$} & \multicolumn{2}{|l|}{$\mathrm{F}$} & 1.348 & \\
\hline & \multicolumn{2}{|l|}{ Sig. } & .255 & \\
\hline & \multirow{2}{*}{\multicolumn{2}{|c|}{${ }_{\mathrm{df}}^{\mathrm{d}}$}} & 102.186 & 102.186 \\
\hline & & & 28 & 23.728 \\
\hline & \multicolumn{2}{|l|}{ Sig. (2-tailed) } & & \\
\hline & \multirow{2}{*}{\multicolumn{2}{|c|}{ Mean Difference }} & & \\
\hline & & & 2.45800 & 2.45800 \\
\hline & \multirow{2}{*}{\multicolumn{2}{|c|}{ Std. Error Difference }} & & \\
\hline & & & .02405 & .02405 \\
\hline & \multirow{2}{*}{$\begin{array}{l}95 \% \text { Confidence Interval } \\
\text { of the Difference }\end{array}$} & Lower & 2.40873 & 2.40832 \\
\hline & & Upper & 2.50727 & 2.50768 \\
\hline
\end{tabular}

Table 1 shows the independent sample $\mathrm{t}$-test score for both groups. The t-test for two different sample groups is done in two stages. The first stage is to examine whether the variance of the two groups can be regarded as identical or not. The second stage is to examine the difference of the average score of the two samples.

As table 2 indicates that the $\mathrm{F}$ score for the equal variances assumed is 1.348 with the probability 0.255 . Since the probability is larger than 0.05 , the two variances are significantly equal. The next stage is to examine if the two mean scores are significantly different or not. The mean difference of the two samples is 2.458 $(4.1213-1.6633=2.458)$. The lower difference in $95 \%$ confidence interval is 2.40873 and the upper difference is 2.50727 . It means that the difference of the writing score of both samples is between 2.40873 and 2.50727 with the average difference is 2.458 . The t-test score for both samples is 102.186. Compared to the 
critical t-table 2.048 for $\alpha 0.05$ with the degree of freedom $\mathrm{df}=28$, the t-test score is much larger or is not in the interval of -2.048 to

2. The Students' Opinions about EGM as A Learning Resource in Learning Spoken English
+2.048 . Since the t-test score is larger than the critical t-table score, both mean scores are significantly different.

Table 3 and 4 below show the two types of calculation results of the students' opinion about EGM as a learning resource in learning spoken English.

Table 3 Descriptive Statistics of Students' Perceptions toward the EGM as A Learning Resource in Learning Spoken English ( $N=15)$

\begin{tabular}{ccc}
\hline Question Number & Mean & Standard Deviation \\
\hline $\mathbf{1}$ & $\mathbf{4 . 6 0}$ & 0.51 \\
\hline $\mathbf{2}$ & $\mathbf{4 . 7 3}$ & 0.46 \\
\hline $\mathbf{3}$ & $\mathbf{5 . 0 0}$ & 0.00 \\
\hline $\mathbf{4}$ & 4.53 & 0.64 \\
\hline $\mathbf{5}$ & 4.60 & 0.51 \\
\hline $\mathbf{6}$ & $\mathbf{4 . 3 3}$ & 0.62 \\
\hline $\mathbf{7}$ & $\mathbf{4 . 7 3}$ & 0.46 \\
\hline $\mathbf{8}$ & $\mathbf{4 . 8 0}$ & 0.41 \\
\hline $\mathbf{9}$ & 4.40 & 0.63 \\
\hline $\mathbf{1 0}$ & 4.47 & 0.64 \\
\hline Average & $\mathbf{4 . 6 2}$ & $\mathbf{0 . 4 9}$ \\
\hline & &
\end{tabular}

*The least number

Mean levels: $\quad 1.00-1.80=$ strongly negative; $1.81-2.60=$ basically negative; $2.61-3.40=$ undecided; 3.41-4.20 = moderately positive; 4.21-5.00 = highly positive

Table 4 Percentage of Students in Five Rating Scales ( $N=15)$

\begin{tabular}{|c|c|c|c|c|c|c|}
\hline No & Statement & $\overline{\mathbf{S A}}$ & MoA & $\overline{\mathbf{N}}$ & $\mathbf{B A}$ & $\mathbf{M i A}$ \\
\hline 1 & $\begin{array}{l}\text { English gossip magazines are good sources for } \\
\text { speaking materials. }\end{array}$ & 60 & 40 & 0 & 0 & 0 \\
\hline 2 & $\begin{array}{l}\text { English gossip magazines made me feels able to } \\
\text { speak freely or without any pressure. }\end{array}$ & 73.33 & 26.67 & 0 & 0 & 0 \\
\hline 3 & $\begin{array}{l}\text { English gossip magazines helped me develop my } \\
\text { self-confidence. }\end{array}$ & 100 & 0 & 0 & 0 & 0 \\
\hline 4 & English gossip magazines were fun and addictive. & 60 & 33.33 & 6.66 & 0 & 0 \\
\hline 5 & $\begin{array}{l}\text { English gossip magazines allowed me constructs } \\
\text { lots of sentences. }\end{array}$ & 60 & 40 & 0 & 0 & 0 \\
\hline 6 & English gossip magazines drove me more assertive. & 40 & 53.33 & 6.66 & 0 & 0 \\
\hline 7 & $\begin{array}{l}\text { English gossip magazines provide me with lots of } \\
\text { new spoken vocabulary. }\end{array}$ & 73.33 & 26.67 & 0 & 0 & 0 \\
\hline 8 & $\begin{array}{l}\text { English gossip magazines provide me with lots of } \\
\text { new spoken expressions. }\end{array}$ & 80 & 20 & 0 & 0 & 0 \\
\hline 9 & $\begin{array}{l}\text { Using English gossip magazines in classroom } \\
\text { speaking was like speaking in a real situation. }\end{array}$ & 46.67 & 46.67 & 6.66 & 0 & 0 \\
\hline 10 & $\begin{array}{l}\text { Using English gossip magazines is highly } \\
\text { recommended to be used as a learning resource in } \\
\text { learning speaking and other skills. }\end{array}$ & 53.33 & 40 & 6.66 & 0 & 0 \\
\hline
\end{tabular}

SA Strongly Agree; MoA Moderately Agree; N Neutral; BA Basically Agree; MiA Minimally Agree 


\section{《E] EDUMASPUL \\ Volume 1 - Nomor 2, Oktober 2017, 1-14 \\ I ISSN 2548-8201 (Print) | 2580-0469)(Online) |}

Table 3 indicates that the five statements the students agree with the most were no. 3,8 , 2,7 and 1 , while statement no. 6 was agreed with the least. The average mean score of the students' opinion about EGM as a learning resource in learning spoken English was 4.62 which can be interpreted as having a high agreement (Highly Positive) with this material.

\section{The Amount of Spoken English Exposed}

In order to investigate the amount of spoken English exposed, the assessment observation format for speaking frequency was administered at the end of every series of
From table 4, the percentage of students marking on each statement was shown in five rating scales. The percentage score ranges from 0 to 100 percent. Among the statements, one of them was rated 100 percent, namely statement No.3 (English gossip magazines helped me develop my self-confidence). None of the students disagreed if this approach could improve their reading skills achievement.

instruction. They were evaluated through the frequency of taking-over the turn in the speaking activities. The frequency tabulation and the mean level were used to investigate how much this behaviour occurred.

Table 5 Amount of Spoken English Produced through Turn-Taking (N=15)

\begin{tabular}{ccccccc}
\hline Sample & Series 1 & Series 2 & Series 3 & Series 4 & Total & Mean \\
\hline $\mathbf{1}$ & 2 & 8 & 10 & 9 & $\mathbf{2 9}$ & $\mathbf{7 . 2 5}$ \\
\hline $\mathbf{2}$ & 1 & 5 & 3 & 5 & $\mathbf{1 4}$ & $\mathbf{3 . 5 0}$ \\
\hline $\mathbf{3}$ & 0 & 8 & 7 & 10 & $\mathbf{2 5}$ & $\mathbf{6 . 2 5}$ \\
\hline $\mathbf{5}$ & 1 & 6 & 6 & 7 & $\mathbf{2 0}$ & $\mathbf{5 . 0 0}$ \\
\hline $\mathbf{6}$ & 0 & 8 & 5 & 5 & $\mathbf{1 8}$ & $\mathbf{4 . 5 0}$ \\
\hline $\mathbf{7}$ & 2 & 5 & 3 & 7 & $\mathbf{1 7}$ & $\mathbf{4 . 2 5}$ \\
\hline $\mathbf{8}$ & 2 & 4 & 4 & 6 & $\mathbf{1 6}$ & $\mathbf{4 . 0 0}$ \\
\hline $\mathbf{9}$ & 1 & 2 & 5 & 7 & $\mathbf{1 5}$ & $\mathbf{3 . 7 5}$ \\
\hline $\mathbf{1 0}$ & 2 & 3 & 6 & 5 & $\mathbf{1 6}$ & $\mathbf{4 . 0 0}$ \\
\hline $\mathbf{1 1}$ & 1 & 6 & 7 & 3 & $\mathbf{1 7}$ & $\mathbf{4 . 2 5}$ \\
\hline $\mathbf{1 2}$ & 0 & 5 & 6 & 4 & $\mathbf{1 5}$ & $\mathbf{3 . 7 5}$ \\
\hline $\mathbf{1 3}$ & 2 & 4 & 4 & 5 & $\mathbf{1 5}$ & $\mathbf{3 . 7 5}$ \\
\hline $\mathbf{1 4}$ & 0 & 8 & 3 & 6 & $\mathbf{1 8}$ & $\mathbf{4 . 5 0}$ \\
\hline $\mathbf{1 5}$ & 0 & 4 & 8 & 7 & $\mathbf{1 9}$ & $\mathbf{4 . 7 5}$ \\
\hline Sum & $\mathbf{1 5}$ & 3 & 4 & 3 & $\mathbf{1 0}$ & $\mathbf{2 . 5 0}$ \\
\hline Mean & $\mathbf{1 . 0}$ & $\mathbf{5 . 3}$ & $\mathbf{5 . 4}$ & $\mathbf{5 . 9}$ & $\mathbf{1 7 . 6}$ & $\mathbf{4 . 4 0}$ \\
\hline
\end{tabular}

Table 5 above shows the amount of spoken English produced through 29 conversation turn-taking in four series. In the first series, there were 15 times of turn-taking made and increases to 79 in the second series. In the third series, the turn-taking increases to 81 times and continues to increase in the last series for 89 times. The average amount of spoken English produced in the first series was 1.0 but then increases to 5.3 in the second series.
However, the tendency tends to level off from the second to the fourth series of $5.3 ; 5.4$; and 5.9 .

The average mean (4.40) can be interpreted as the students in all series having less opportunity (Less Frequent) to frequently produce spoken English. The highest mean (5.9) focused on the last series, and the lowest mean (1.0) belongs to the first series. 


\section{DISCUSSION}

\section{The Improvement of the Students' Enthusiasm in Learning Spoken English through Gossip Materials from EGM}

First of all, enthusiasm in learning spoken English arises when learners are exposed to closely related and meaningful situations from their environment, such as gossip materials. A great body of research has demonstrated that enthusiasm in speaking is one of the most important predictors of language performance, and it needs to be distinguished from other forms of enthusiasm as in some religious faith (Webster, 2008).

As Harmer (1991) reported, language serves as a tool for communication which conveys our ideas through different channels such as words, pictures, or other symbols. Communication, a function of social interaction, involves linguistic elements, intrapersonal emotional display, and external interpersonal skills. When a student's enthusiasm is high, his or her spoken English production may be well released without anxiety. Therefore, the issue of enthusiasm becomes more important in foreign language learning and teaching.

In this study, the major purpose was to investigate the positive impacts of gossip materials from EGM on students' enthusiasm in using spoken English. The first research question investigated the students' enthusiasm in learning spoken English through gossip topics taken from EGM. To accomplish this, the students were first observed and rated on the modified instrument of Observation for Enthusiasm in four series of time. The results suggest that the subjects of this study seem to increase their level of enthusiasm although at first they have relatively low level of enthusiasm in learning spoken English. Moreover, their peers in the control group have relatively low level of enthusiasm in learning spoken English as they used different materials for the treatment in four series of time. Evidence shows that students who are exposed to gossip materials taken from webzines tend to be more enthusiastic in learning to speak spoken English (Lundquist, 2008) and it supports the theory that enthusiasm in language teaching context could be attained through certain sources with certain stimuli (Donaghy, McGee, Usher and Yates, 2003; and Webster, 2005).
In essence, the findings of this research suggest that enthusiasm in speaking is a crucial factor for students to develop their confidence and to reduce their anxiety level. Gossip materials about celebrities taken from magazines or webzines are very effective to improve the students' enthusiasm to a greater extent as they do not have to pay careful attention to the content of gossips. As soon as their enthusiasm is improved, they will share positive values on such materials. By the same token, they will produce more spoken English through informal conversation in which they do not have to be concerned with slips or grammatical errors as spoken English is naturally full of paratactic and paralinguistic features.

\section{The Students' Opinions about EGM as A Learning Resource in Learning Spoken English}

Research question two attempted to reveal the students' opinions about the use of EGM as a learning resource for spoken English. The major findings of this quasi-experimental research suggested that students shared positive opinions about EGM as a learning resource in spoken English as they are more enthusiastic in doing such activities. Therefore, the second hypothesis is accepted. The results reveal that as the students have successfully improved their enthusiasm, they valued EGM positively and disregarded the negative impact of gossips.

As a matter of fact, the students in general are potential to have better achievement or better attention and respects if only the individual characteristics of the students are taken into account and the environments can be made to be more meaningful. The use of EGM can be used as an alternative to empower the students' brain to a large extent. According to the proponent of Brain-Based Learning, Jensen (1996:93), human brain is designed to find meaning. Anything can have meaning if the thing itself is important and meaningful to individuals.

These main principles can be set in several components. Here, he believes that teaching will be 'enlightened' if there is a kind of collaboration between teacher's own practice (what teachers do in the classroom) and theory (a kind of pedagogy theory from research). This kind of collaboration is gained from the teaching 
principles to 'intrinsic factor'. These cognitive principles envelop automatic learning, meaningful learning, and the anticipation of reward, the intrinsic motivation principle, and strategic investment. Thus, reward is one of human necessities and may give a big effect for students' success as Browns (1994) states that rewards in teaching learning process have a high impact on classroom instruction. It is an extrinsic motivation beside intrinsic motivation.

\section{The Amount of Spoken English Produced through EGM Exposures}

Research question three attempted to find out how much the students spoke spoken English when they were exposed to gossip materials from EGM. The findings provide evidence that the students were more and more talkative and produced more spoken English. As the majority of the students showed their enthusiasm in speaking, they opportunity to speak more spoken English was becoming lesser. This is a normal nomenon that when they share the turn-taking more equally, they would have less chance to produce more utterances. Evidence supports the theory that students needed some kind of internal drive called enthusiasm served as energy enhancer, goal maintainer, curiosity gripper, interest presenter, fire igniters, fear reducer, worry dissolver, and apathy eliminator in learning spoken English (Sanders and Gosenpud, 1986; Hyken, 2008; and Poggi, 2007).

This study showed that EGM was a significant factor in improving students' enthusiasm in using spoken English. The impact of this is that such intervention designed to improve foreign language learning is strongly recommended and it is believed that this intervention may be enhanced by topics of interest to make materials more meaningful to students. Gossip materials from magazines and webzines or other resources can be modified to meet learning objectives such as learning to speak spoken English. This will, in turn, produce automatization in learning a language and will result in the improvement of learning either in quantity or in quality.

Brown (1994) states the principle of automatic learning closely relates to the ability of children in acquiring foreign language subconsciously. Here, automatic learning sees the 'gradation' system of a child in learning language-unit by unit, piece by piece, focusing closely on each. The automatic learning principle mainly focuses on the usage of language through meaningful use in which the lessons make a balance between formal aspects of language and the functional purpose of language. Automatic learning cannot be gained in a short time but it is a process in which patience with students is needed. Meaningful learning correlates with the principle of automatic learning that is the lesson does not consist only of grammar but also highlights the students' interests, academic goals and career goals. It stresses the materials in which language associates with sounds, words, structures and discourse elements that will be relevant and important to the students' daily quest of knowledge and survival.

\section{CONCLUSIONS}

This chapter concludes the findings and the discussion following by remarks the researcher would like to share. Some suggestions or recommendations are also proposed after the concluding remarks.

\section{A. Conclusions}

Based on the findings and discussion, the researcher concludes the following things:

1. The students' enthusiasm in learning spoken English improved to a greater extent through gossip topics taken from EGM. The mean scores improved from 1.75 to 4.12 in four series of time and are classified as from 'Unenthusiastic' to 'Highly Enthusiastic'. The average increase of the mean scores of the experimental group was about 49.62 percent. The two mean scores of the experimental and control group were significantly different. The t-test score for both samples is 102.186. Compared to the critical t-table 2.048 for $\alpha 0.05$ with the degree of freedom $\mathrm{df}=28$, the t-test score is much larger or is not in the interval of 2.048 to +2.048 . Since the t-test score is larger than the critical t-table score, both mean scores are significantly different.

2. The students valued EGM positively as their enthusiasm improved to a greater extent. The five statements the students agree with the most were No. 3, 8, 2, 7 and 1, while statement No. 6 was agreed with the least. The average mean score of the students' 
opinion about EGM as a learning resource in learning spoken English was 4.62 which can be interpreted as having a high agreement (Highly Positive) with this material. Besides, the students agreed that EGM helped them develop their confidence). None of the students disagreed if this approach could improve their reading skills achievement.

3. The average amount of spoken English produced in the first series was 1.0 but then increases to 5.3 in the second series. However, the tendency tends to level off from the second to the fourth series of 5.3; 5.4; and 5.9. The average mean (4.40) can be interpreted as the students in all series having less opportunity (Less Frequent) to frequently produce spoken English. The highest mean (5.9) focused on the last series, and the lowest mean (1.0) belongs to the first series.

\section{B. Suggestions}

As the results of the study reveal that EGM had been effective to improve the students' enthusiasm in speaking spoken English, the researcher suggests the following things:

\section{References:}

[1] Bissex, G.L. (1980) Guys at Work. Cambridge, Mass.: Harvard University Press.

[2] Definition of Enthusiasm. (2008). Retrieved from http://www.brainyquote.com/ on February 6, 2009.

[3] Brown, G. (1978). "Understanding spoken language", TESOL Quarterly, 12, 3:27183.

[4] Brown, G. and Yule, G. (1983a). Teaching the Spoken Language, An Approach Based on the Analysis of Conversational English. Cambridge: Cambridge University Press.

[5] Brown, H. D. (1994). Teaching by Principles. New Jersey: Prentice Hall Regent, Inc.

[6] Cambridge Advanced Learner Dictionary. (2008). CD-ROM Version.

[7] Chavez, M. (1988). "Learner's perspectives on authenticity", International Review of Applied Linguistics in Language Teaching, 36(4), pp277-290.
1. The use of gossip topics from EGM is highly recommended to be used by teachers of EFL especially if the learning focuses on spoken English.

2. A replication of the study could be conducted with other groups at the same or different levels focusing in speaking or writing. It would be worthwhile to investigate how effective EGM on the other skill so that instructors can use findings for improving and developing their teaching process.

3. As this research is mainly based on materials development using authentic materials, future research should focus on comparisons among different models of authentic materials in order to determine if other resources are equally effective in producing desired students.

4. To examine students' attitudes on EGM, the instrument can be developed to be more elaborative to get a more comprehensive data about the students' attitudes and can be followed by interviewing some students about their real feeling or impressions about this model.

[8] Clarke, D. (1990). "Communicative theory and its influence on materials production", Language Teaching 25(1), pp73-86

[9] Clive, C. (2009). "Learning through Talking: A Contribution towards the moral environment of Seven-Year-Olds provided by an Environmental Project." Educational Review, 39 (1), 47-53. [EJ 351 843]

[10] Coats, W. D. and Smidchens, U. (1966). "Audience recall as a function of speaker dynamism", Journal of Educational Psychology, 57, pp89-91

[11] Cruichshank, D. R. (1980). Teaching is Tough. New Jersey: Englewood Cliffs.

[12] Donaghy, A., McGee, C., Ussher, B. and Yates, R. (2003). Online Teaching and Learning: A Study of Teacher Education Students' Experiences. Hamilton, NZ: Wilf Malcolm Institute of Educational Research

[13] Guariento, W. and Morley, J. (2001).Text and task authenticity in the EFL classroom. ELT Journal 55(4), pp347-353.

[14] Halliday, M.A.K. (1978). Language as Social Semiotic. London: Edward Arnold. 
[15] Harmer, J. (1991). The Practice of English Language Teaching. London: Longman.

[16] Hyken, S. (2008). Enthusiasm - It Is Contagious. Ohio: Kmalhotra Publishers.

[17] Jensen, E. (2000). BBL: The New Science of Teaching and Training. San Diego: The Brainstore

[18] Jordan, R. R (1997). English for Academic Purposes: A Guide and Resource for Teachers. Cambridge. Cambridge University Press.

[19] Kilickaya, F. (2004). "Language, authentic materials and cultural content in EFL classrooms", The Internet TESL Journal, 10 (7). Retrieved from http://iteslj.org/Techniques/Kilickaya-

AutenticMaterial.html on December 27, 2008.

[20] Kitao, K. and Kitao S.K. (2003). "Selecting and developing teaching/learning materials", In K. Kitao and S. K. Kitao. English teaching: Theory, Research and Practice (pp. 205-216). Tokyo: Eichosha.

[21] Lundquist, L. (2008). Learning A Spoken Second Language: How to Speak Fluently in Less Time - in An Established School or When Studying Alone. (Online). Retrieved from www.FreeEnglishNow.com on January 4, 2009.

[22] Martinez, A. (2002). Authentic materials: An overview. Karen's Linguistic Issues. Retrieved from

[23] http://www3.telus.net/linguisticsissues/a uthenticmaterials.html on January 9, 2009.

[24] Patricia, S. G. (2001). Talking Classrooms: Shaping Children's Learning Through Oral Language Instruction. Newark, DE: International Reading Association.

[25] Peacock, M. (1997). "The effect of authentic materials on the motivation of EFL learners", ELT Journal, 51(2), pp144 $-153$.

[26] Peale, N. V. (1973). Enthusiasm, The Action Handbook: What It Can Do for You. New York: Foundation for Christian Living.

[27] Pheng, P. T. (2003). "Confidence and fluency in spoken English of Vietnamese students through the topic of interests". Unpublished Postgraduate Thesis. Clayton: Monah University

[28] Philips, M . K. and Shettlesworth, C. (1978). "How to arm your students: A consideration of two approaches to providing materials for ESP". In English for Specific Purposes. ELT Documents 101. London: ETIC Publications, British Council, pp. 23-35.

[29] Poggi, I. (2007). Enthusiasm and Its Contagion: Nature and Function. Berlin: Heidelberg.

[30] Richards, J. (1983). "Listening comprehension: Approach, design, procedure. TESOL Quarterly, 17(2): pp. 219-239.

[31] Richards, J. C. (2001). Curriculum Development in Language Teaching. Cambridge: Cambridge University Press.

[32] Rosenshine, B. (1970). "Enthusiastic teaching: A research review". School Review, 78, pp.499-514

[33] Sanders, P., and Gosenpud, J. (1986). Developments in Business Simulation \& Experiential Exercises: Perceived instructor enthusiasm and student achievement. Retrieved from http://sbaweb.wayne.edu/ absel/bkl/vol13/ 13al.pdf on 24 February 2009.

[34] Sanderson, P. (1999), Using Newspapers in the Classroom. Cambridge: Cambridge University Press

[35] Setiyadi, Ag. B. (2006). Metode Penelitian untuk Pengajaran Bahasa Asing, Pendekatan Kuantitatif dan Kualitatif. Yogyakarta: Graha Ilmu

[36] Tinnefeld, T. and Yeh, Y.L.L. (2007). "English gossip magazines as a source of spoken language learning materials", (Abstract 20). In $5^{\text {th }}$ Asia TEFL International Conference 2007 Kuala Lumpur, Malaysia, pp.95-96. Kuala Lumpur: Melta

[37] Webster, A. S. (2005). Enthusiasm! How to Draw It and Keep It for Yourself. Ohio: Inscape Publishing.

[38] Wells, J. C. (1982). Accents of English. Cambridge: Cambridge University Press.

[39] Widdowson, H. (1990). Aspects of Language Teaching. Oxford: Oxford University Press. 